\title{
PCR for detection and identification of Streptococcus sobrinus
}

\author{
T. IGARASHI, A. YAMAMOTO and N. GOTO \\ Department of Oral Microbiology, Showa University School of Dentistry, 1-5-8 Hatanodai, Shinagawa-ku, \\ Tokyo 142-8555, Japan
}

\begin{abstract}
Oligonucleotide primers were designed based upon a comparison of the dextranase gene (dex) sequences from Streptococcus sobrinus and $S$. mutans. The primers amplified a 1610-bp long DNA fragment on the dex gene by a PCR. The pair of primers was specific to $S$. sobrinus as the other members of the mutans streptococci - S. mutans, $S$. downei, $S$. cricetus, S. rattus, $S$. macacae and $S$. ferus - gave no PCR products. Other grampositive oral bacteria (15 strains of 10 species of cocci and 18 strains of 12 species of rods) and gram-negative oral bacteria (3 strains of 3 species of cocci and 31 strains of 22 species of rods) also gave negative results in the PCR. The PCR procedure was able to detect as little as $100 \mathrm{fg}$ of purified chromosomal DNA or as few as 9 cfu of $S$. sobrinus NIDR6715. Seven clinical isolates of $S$. sobrinus were also positive in the dex PCR. This laboratory developed the $S$. mutans-specific PCR (dexA PCR) method with the primers specific for a portion of the dextranase gene of $S$. mutans Ingbritt. Primers for the $\operatorname{dex}$ and $\operatorname{dexA}$ PCR methods detected two species exclusively from the mutans streptococci. Furthermore, these two species were effectively differentiated by the species-specific amplicons with different lengths. The application of the PCR method to human dental plaque showed that the prevalence of $S$. sobrinus $(83 \%)$ in oral cavities was higher than currently supposed $(0-50 \%)$. These results suggest that the described PCR method is suitable for the specific detection and identification of human cariogenic bacteria, S. sobrinus and $S$. mutans.
\end{abstract}

\section{Introduction}

The mutans group of oral streptococci consists of seven species: Streptococcus cricetus, S. rattus, S. mutans, $S$. sobrinus, $S$. downei, $S$. macacae and $S$. ferus [1]. Among the group, $S$. mutans and $S$. sobrinus are most frequently isolated from human dental plaque and closely associated with human dental caries [2,3]. Prevalence of $S$. sobrinus and $S$. mutans in the human oral cavity has been reported by epidemiological studies in which the isolation frequency of $S$. mutans from dental plaque is much higher than that of $S$. sobrinus [3-5]. The primary differentiation of these cariogenic species is usually based on the colonial morphology on mitis-salivarius (MS) or MS-bacitracin (MSB) agar [5-9]; the isolated colonies are then identified by biochemical, immunological and genetic tests $[2,10-12]$. However, this procedure is sometimes inaccurate, and also time-consuming and laborious.

Received 24 Jan. 2000; accepted 20 Feb. 2000.

Corresponding author: Dr T. Igarashi (e-mail: igatakes@, dent.showa-u.ac.jp).
New tools such as DNA probes and PCR primers may be required to overcome these limitations. Smorawinska and Kuramitsu [13] and Colby et al. [14] developed DNA probes which hybridised the $g t f B$, ftf and wapA genes of S. mutans, and Ono et al. [15] and Colby et al. [14] designed PCR primers for spaP and wapA genes, respectively. On the other hand, work at this laboratory focused on the dextranase genes (dex) of cariogenic species for detection and identification. Dextranase is an enzyme that hydrolyses glucans in a plaque matrix and is believed to be involved in the pathogenesis of dental caries [16,17]. The enzymes produced by $S$. mutans and $S$. sobrinus have been well studied to some extent, [16-22] and so far the DNA probe and PCR primers have been designed for the $S$. mutans dex gene to establish the species-specific DNA probe and PCR methods for detecting and identifying $S$. mutans $[23,24]$.

In this study, PCR primers were designed to amplify the dex gene of $S$. sobrinus to establish a simple, rapid and specific method for the detection and identification of $S$. sobrinus by PCR. Direct detection of $S$. sobrinus 
and $S$. mutans in human dental plaque by the $S$. sobrinus- and $S$. mutans-specific PCR methods was also tried and the prevalence of these cariogenic species in oral cavities was examined.

\section{Materials and methods}

\section{Bacterial strains}

All bacterial strains used in this study, which were maintained and grown as described previously [24], are listed in Table 1. Escherichia coli strain JM109 was grown on LB agar plates.

\section{Oligonucleotide primers and PCR procedure}

Oligonucleotide primers, SOF14 and SOR1623, were designed to amplify a 1610-bp fragment on the dex DNA sequence of $S$. sobrinus UAB66 (GenBank accession no. M96978) [22]. The nucleotide sequences of SOF14 and SOR1623 were 5'-TGC TAT CTT TCC CTA GCA TG-3' (positions 134-153) and 5'-GGT ATT CGG TTT GAC TGC-3' (positions 1743-1726), respectively. PCR was performed as described previously [24]. Briefly, the reaction mixture $(50 \mu l)$ was denatured at $95^{\circ} \mathrm{C}$ for $3 \mathrm{~min}$ followed by a series of amplification: denaturation at $95^{\circ} \mathrm{C}$ for $1 \mathrm{~min}$, annealing at $55^{\circ} \mathrm{C}$ for $1 \mathrm{~min}$ and extension at $72^{\circ} \mathrm{C}$ for $1 \mathrm{~min}$. The series was repeated for 26 cycles. The final cycle comprised $94^{\circ} \mathrm{C}$ for $1 \mathrm{~min}, 55^{\circ} \mathrm{C}$ for $1 \mathrm{~min}$ and $72^{\circ} \mathrm{C}$ for $5 \mathrm{~min}$. The PCR products were subjected to electrophoresis on a $1.0 \%$ or $1.5 \%$ agarose gel and stained with ethidium bromide.

\section{DNA preparation}

Chromosomal DNAs of mutans streptococci, S. sanguis, S. gordonii, and $S$. salivarius, were purified as

Table 1. Bacterial strains used in this study

\begin{tabular}{|c|c|}
\hline \multicolumn{2}{|l|}{ Gram-positive cocci } \\
\hline Enterococcus faecalis $4532 \mathrm{D}$ & S. sobrinus ATCC 33478 \\
\hline Gemella morbillorum ATCC 27824 & S. downei NCTC 11391 \\
\hline Streptococcus cricetus E49 & S. ferus ATCC 33477 \\
\hline S. cricetus HS6 & S. macacae ATCC 35911 \\
\hline S. rattus $\mathrm{BHT}$ & S. sanguis ATCC 10556 \\
\hline S. rattus $\mathrm{FA} 1$ & S. gordonii ATCC 10558 \\
\hline S. mutans ATCC 25175 & S. salivarius ATCC7073 \\
\hline S. mutans ATCC 33535 & S. salivarius KT12 \\
\hline S. mutans GS5 & S. mitis ATCC 903 \\
\hline S. mutans Ingbritt & S. mitis ATCC 9811 \\
\hline S. mutans JCM 5175 & S. mitis IID39 \\
\hline S. mutans LM7 & S. anginosus ATCC 9895 \\
\hline S. mutans MT703 & S. bovis ATCC 9809 \\
\hline S. mutans OMZ175 & S. pyogenes ATCC 10389 \\
\hline S. sobrinus OMZ176 & S. pyogenes ATCC 12348 \\
\hline S. sobrinus NIDR6715 & Streptococcus sp. ATCC 12388 \\
\hline S. sobrinus ATCC 27607 & Streptococcus sp. ATCC 12394 \\
\hline \multicolumn{2}{|l|}{ Gram-positive rods } \\
\hline Actinomyces viscosus ATCC 19246 & L. casei JCM 1134 \\
\hline Act. viscosus ATCC 15987 & Propionibacterium acnes ATCC 6919 \\
\hline Act. naeslundii ATCC 12140 & P. acnes ATCC 11827 \\
\hline Act. israelii ATCC 12102 & P. acnes ATCC 11828 \\
\hline Act. israelii ATCC 12836 & P. granulosum ATCC 11829 \\
\hline Act. odontolyticus ATCC 12929 & P. propionicum ATCC 29324 \\
\hline Corynebacterium matruchotii ATCC 14266 & P. propionicum ATCC 29326 \\
\hline Lactobacillus acidophilus JCM 1132 & Rothia dentocariosa ATCC 14189 \\
\hline L. alactosus JCM 1133 & R. dentocariosa ATCC 14190 \\
\hline \multicolumn{2}{|l|}{ Gram-negative cocci } \\
\hline Veillonella atypica ATCC 17744 & V. dispar ATCC 17748 \\
\hline V. parvula ATCC 17745 & \\
\hline \multicolumn{2}{|l|}{ Gram-negative rods } \\
\hline $\begin{array}{l}\text { Actinobacillus actinomycetemcomitans ATCC } \\
29522\end{array}$ & Por. endodontalis ATCC 35406 \\
\hline A. actinomycetemcomitans ATCC 29523 & Por. gingivalis ATCC 33277 \\
\hline A. actinomycetemcomitans ATCC 29524 & Por. gingivalis 381 \\
\hline A. actinomycetemcomitans ATCC 33384 & Prevotella. denticola ATCC 33185 \\
\hline A. actinomycetemcomitans Y4 & Pr. intermedia ATCC 15032 \\
\hline Bacteroides gracilis ATCC 33236 & Pr. intermedia ATCC 25261 \\
\hline B. macacae ATCC 33141 & Pr. intermedia ATCC 25611 \\
\hline Campylobacter curvus ATCC 35224 & Pr. intermedia VIP 4197 \\
\hline C. rectus ATCC 33238 & Pr. loescheii ATCC 15930 \\
\hline C. showae ATCC 51146 & Pr. melaninogenica ATCC 25845 \\
\hline Capnocytophaga gingivalis ATCC 33624 & Pr. nigrescens ATCC 33563 \\
\hline Cap. ochracea ATCC 27872 & Pr. oralis ATCC 33269 \\
\hline Cap. sputigena ATCC 33612 & Pr. oralis $\operatorname{Ig} 4 \mathrm{a}$ \\
\hline Eikenella corrodens ATCC 23834 & Selenomonas flueggeii ATCC 43531 \\
\hline Fusobacterium nucleatum ATCC 25586 & Sel. infelix ATCC 43532 \\
\hline Porphyromonas asaccharolytica ATCC 25260 & \\
\hline
\end{tabular}


reported previously [20]. Chromosomal DNA from the other gram-positive bacteria and clinical isolates of $S$. sobrinus and $S$. mutans was extracted by the chloroform method of Gillespie et al. [24, 25]. Chromosomal DNA from gram-negative bacteria was purified by the method of Marmur [26]. Chromosomal DNA was extracted from dental plaque by the SDS-lysis method as described previously [24]. Plasmid DNA was isolated by a Wizard Miniprep Purification Kit as indicated by the manufacturer (Promega, Madison, WI, USA).

\section{Nucleotide sequence analysis}

PCR products were cloned into a pT7Blue T-vector (Novagen, Madison, WI, USA) and sequenced with an ABI Prime Cycle Sequencing Kit and a model 373S automated DNA sequencer (Perkin Elmer Applied Biosystems, Foster City, CA, USA) as described previously [20]. Nucleotide and deduced amino-acid sequences were analysed with Genetyx-Mac software (version 10.1, Software Development, Tokyo, Japan).

\section{Isolation of $S$. sobrinus clinical isolates from human dental plaque}

Clinical isolates of $S$. sobrinus were screened and isolated as described previously [24]. Briefly, supragingival plaque was collected from human subjects and suspended in phosphate-buffered saline and cultured on MS plates. S. sobrinus was initially screened on the basis of colonial morphology on the MS plates and then characterised biochemically with API STREP 20 (bioMérieux, La Balme des Grottes, France). Isolates YK13 and YK42 were characterised as $S$. sobrinus in this laboratory, and isolates MKS4A, MKS4B, MKS13A, MKS27A and MKS100A, which were characterised by biochemical and immunological tests, were kindly provided by Professor K. Fukushima (School of Dentistry at Matsudo, Nihon University, Chiba, Japan). S. mutans isolates from dental plaque which were obtained previously [24] were also used in this study.

\section{Results}

\section{Specificity of oligonucleotide primers}

Oligonucleotide primers (SOF14 and SOR1623) were designed on the nucleotide sequence of the dex gene of $S$. sobrinus on the basis of a sequence comparison between $S$. sobrinus and $S$. mutans dextranase genes. To examine the specificity of the primers to detect the $S$. sobrinus dex gene, PCR was performed with all the strains shown in Table 1 . Of 19 strains of the mutans streptococcal group, only four strains of $S$. sobrinus gave a PCR product that corresponded to the 1610-bp DNA fragment as predicted from the sequence data (Fig. 1, lanes 5-8); none of the other mutans streptococcal species was positive (Fig. 1). Amplified DNA was detected in no other gram-positive species (15 strains of 10 species of cocci and 18 strains of 12 species of bacilli) or gram-negative species ( 3 strains of 3 species of cocci and 31 strains of 22 species of bacilli). To confirm that the PCR-amplified fragment was derived from the dex gene of $S$. sobrinus, the nucleotide sequence of the fragment was determined after cloning into the pT7Blue T-vector. The resultant sequence was the same as reported previously [22]. These results indicate that the PCR method used was specific to $S$. sobrinus.

\section{Sensitivity of the PCR}

The sensitivity of this PCR method was tested with known amounts of $S$. sobrinus NIDR6715 DNA as a template. Chromosomal DNA serially diluted from $1 \mathrm{ng}$ to $1 \mathrm{fg}$ was used as templates in the PCR. The detection limit was $100 \mathrm{fg}$ of template DNA (Fig. 2a, lane 5). The detection sensitivity was also examined with serially diluted $S$. sobrinus NIDR6715 cells. The PCR gave a detectable amount of DNA fragment from

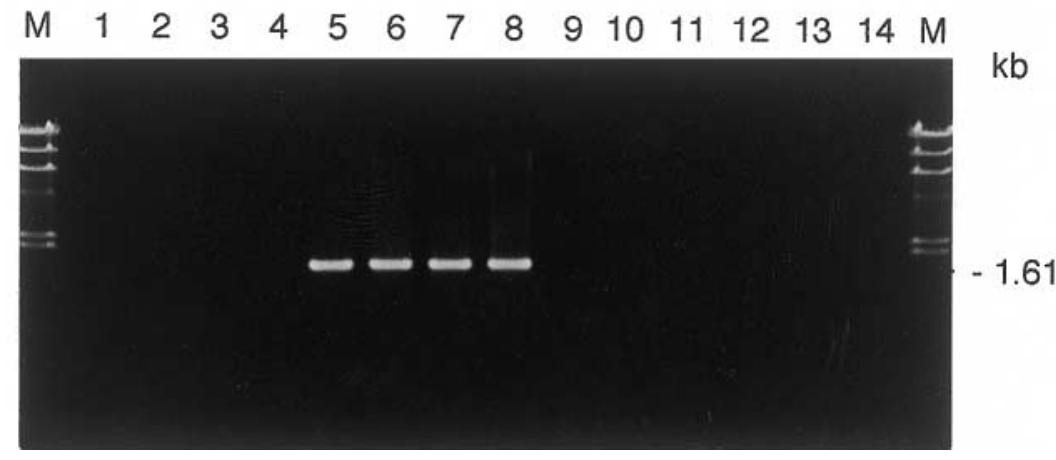

Fig. 1. PCR amplification of the dex DNA sequence on chromosomal DNAs from strains of mutans streptococci. Lane 1. S. cricetus HS6; 2, S. rattus FA1; 3, S. mutans IFO13955; 4, S. mutans JCM5175; 5, S. sobrinus OMZ176; 6, S. sobrinus NIDR6715; 7, S. sobrinus ATCC27607; 8, S. sobrinus ATCC33487; 9, S. downei NCTC11391; 10, S. ferus ATCC33477; 11, S. macacae ATCC35911; 12, S. sanguis ATCC10556; 13, S. gordonii ATCC10558; 14, S. salivarius ATCC7073; M, $\lambda$ DNA digested with HindIII. 
a

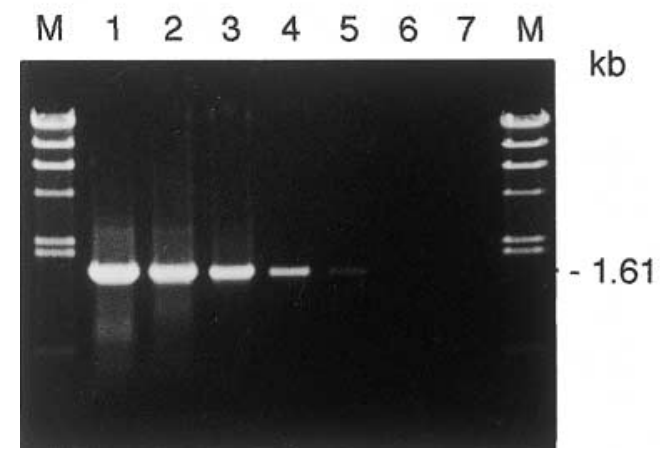

b

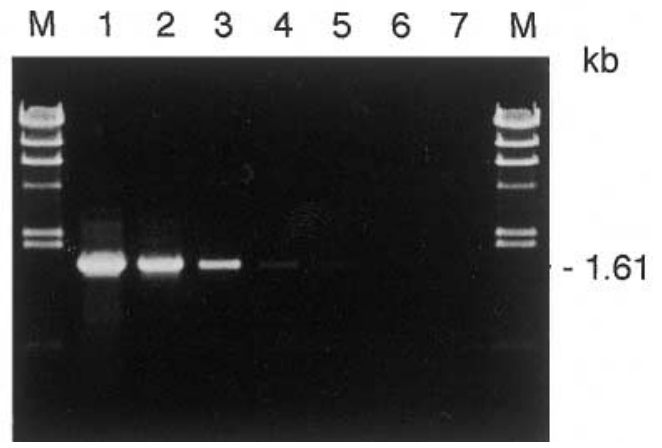

Fig. 2. Sensitivity of the dex PCR with (a) purified chromosomal DNA from $S$. sobrinus NIDR6715 and (b) the lysed cells of $S$. sobrinus NIDR6715. (a) Amount of purified DNA in lanes: 1, $1 \mathrm{ng} ; \mathbf{2}, 100 \mathrm{pg} ; \mathbf{3}, 10 \mathrm{pg} ; \mathbf{4}, 1 \mathrm{pg} ; \mathbf{5}, 100 \mathrm{fg} ; \mathbf{6}$, $10 \mathrm{fg} ; 7,1 \mathrm{fg} ; \mathbf{M}, \lambda$ DNA digested with HindIII. (b) Number of lysed cells in lanes: $\mathbf{1}, 9 \times 10^{3} ; \mathbf{2}, 9 \times 10^{2} ; \mathbf{3}, 9 \times 10^{1}$; $\mathbf{4}, 9 ; \mathbf{5}, 4 ; \mathbf{6}, 2 ; \mathbf{7}, 1 ; \mathbf{M}, \lambda$ DNA digested with HindIII.

the DNA sample prepared by the SDS-lysis method [24] from the cells of as few as 9 cfu (Fig. 2b, lane 4).

\section{Evaluation of the PCR with clinical isolates and human dental plaque}

PCR primer pairs of $S$. sobrinus (this study) and $S$. mutans [24] were used for the detection of these two species. The primer pairs specifically amplified speciesspecific amplicons of different sizes (1610 and $1272 \mathrm{bp}$, respectively) from dextranase genes of $S$. sobrinus and S. mutans (Fig. 3, lane 8) and PCRamplification by the primer pairs yielded the speciesspecific amplicons from each clinical isolate of the species tested (Fig. 3, lanes 1-7 and 9-15). These results indicate that the primer pairs of $S$. sobrinus and $S$. mutans amplified the species-specific amplicons with different lengths, indicating that the present PCR method is useful for detection and identification of the human cariogenic species, $S$. sobrinus and $S$. mutans.

To investigate the prevalence of $S$. sobrinus and $S$. mutans in the human oral cavity, direct detection of these two species was applied to dental plaque samples. A representative example of detection by PCR is shown in Fig. 4. Two different detection patterns were observed: one was positive for $S$. mutans but negative for $S$. sobrinus (Fig. 4, lanes 1 and 4) and the other was positive for both species (Fig. 4, lanes 2, 3, 5-7). To exclude the possibility of non-specific amplification products, the PCR products $(1.61 \mathrm{~kb}$ for $S$. sobrinus and $1.27 \mathrm{~kb}$ for $S$. mutans) obtained from dental plaque were sequenced after cloning into the pT7Blue Tvector; care was taken to ensure that the PCR products were derived from the dextranase gene sequences of $S$. sobrinus and $S$. mutans (data not shown). This analysis was extended to dental plaque samples from 23 individuals. As shown in Table 2, an S. mutans-specific amplicon was detected in the dental plaque samples from all 23 individuals: the prevalence of $S$. mutans was $100 \%$. In contrast, the amplicon specific to $S$. sobrinus was obtained from 19 of 23 individuals: the prevalence of $S$. sobrinus was $83 \%$, which was higher than previously reported $(0-50 \%)$ [3-5].

\section{Discussion}

An earlier study designed oligonucleotide primers for the dex gene of $S$. mutans Ingbritt, which amplified a 1272-bp fragment by PCR. The method was species-

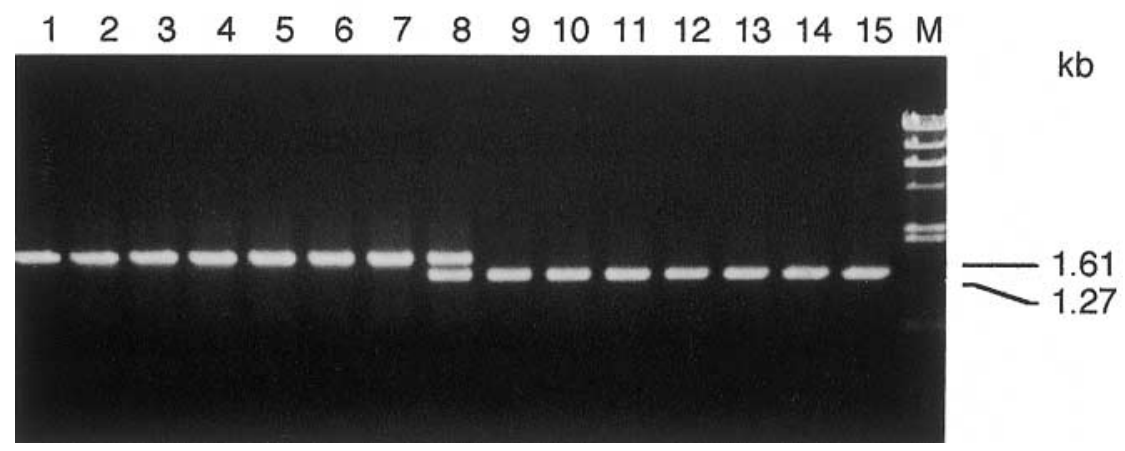

Fig. 3. PCR amplification of DNA of oral isolates of S. sobrinus and S. mutans. Chromosomal DNA was amplified with the primers for either $S$. sobrinus or $S$. mutans. Source of DNA: lanes 1-7, isolates of S. sobrinus from different individuals; 9-15, isolates of $S$. mutans from different individuals; $\mathbf{M}, \lambda$ DNA digested with HindIII; 8, positive control containing the PCR products from S. sobrinus ATCC27607 and S. mutans IFO13955. 


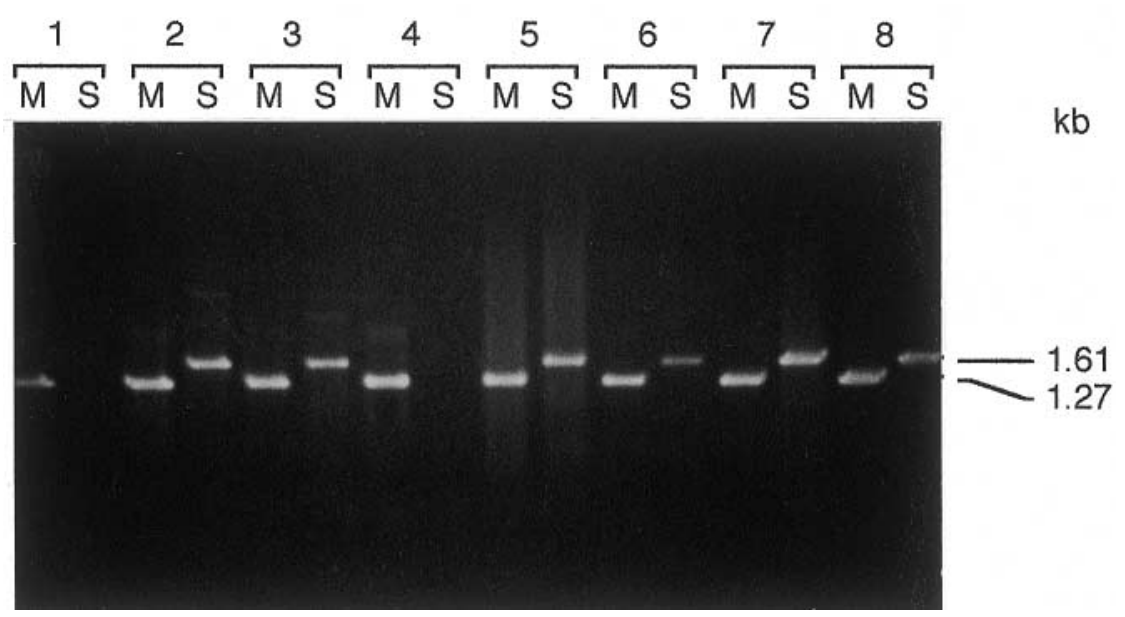

Fig. 4. Direct detection of $S$. mutans and $S$. sobrinus in dental plaque by PCR amplification. Lanes 1-7, dental plaque samples from different individuals were amplified with species-specific primers; M, S. mutans-specific primers; S, S. sobrinus-specific primers; 8, PCR products of (M) S. mutans IFO13955 and (S) S. sobrinus ATCC27607.

Table 2. PCR detection of cariogenic bacteria from human dental plaque

\begin{tabular}{lcc}
\hline Species & $\begin{array}{c}\text { Number } \\
\text { tested }\end{array}$ & $\begin{array}{c}\text { Number positive } \\
\text { by PCR }(\%)\end{array}$ \\
\hline S. mutans & 23 & $23(100)$ \\
S. sobrinus & 23 & $19(83)$ \\
\hline
\end{tabular}

specific, and could detect and identify S. mutans directly from dental plaque [24]. The present study attempted to establish a PCR method for another human cariogenic bacteria, S. sobrinus, under the same conditions as those for $S$. mutans. Oligonucleotide primers were designed for the dex gene of $S$. sobrinus UAB66 based on the comparison of the dex gene sequences of $S$. sobrinus and $S$. mutans $[20,22]$. Two sets of primer pairs were prepared: one (SOF14 and SOR1623) was designed to amplify a 1610-bp fragment (Materials and methods) and the other (SOF14 and SOR762) was expected to amplify a 748-bp fragment (data not shown). The sequence of SOR762 was 5'-ATT GTC AGC GTC ACG CAC G-3' (positions 882-864). Each primer pair gave a single amplicon specifically. Although the primer pair SOF14 and SOR1623 could detect $100 \mathrm{fg}$ of $S$. sobrinus DNA (Fig. 2a), the other primer pair (SOF14 and SOR762) could detect only DNA of $>10 \mathrm{pg}$ (data not shown). Therefore, the primer pair SOF14 and SOR1623 was used in this study.

Some authors have shown that $S$. mutans is more prevalent than $S$. sobrinus in the oral cavity [3-5]. It should be noted that their estimation depended on colony morphology and $S$. sobrinus was screened by bacitracin susceptibility $[7,9,27]$. Therefore, it is conceivable that the actual incidence of $S$. sobrinus may be higher than currently supposed. To understand more fully the relationship between caries incidence and the actual carrier rates of $S$. sobrinus and $S$. mutans, it would be necessary to evaluate the presence of these species in the oral cavity more directly without a cumbersome culture step. To resolve this issue, establishment of a PCR-based method, which is more rapid, more sensitive and simpler, would be suitable. In addition to the $S$. mutans-specific PCR primers which were previously established [24], PCR primers specific to $S$. sobrinus were introduced in this study. Not only could the two primer pairs detect their target DNAs with equal sensitivity and specificity, but they gave amplicons of different lengths which could be distinguished easily from each other ([24] and this study). The PCR method was further evaluated with clinical isolates of $S$. sobrinus and $S$. mutans; the isolates were effectively differentiated by the PCR (Fig. 3). Whereas the conventional procedures to detect cariogenic bacteria from dental plaque usually take a long time (c. 1 week), use of the PCR method described here shortens the time: it is possible to determine the presence of $S$. sobrinus and $S$. mutans in the oral cavity within 1 day $(6-7 \mathrm{~h})$ because the bacterial culture and other cumbersome procedures are omitted.

Although this PCR procedure directly detected $S$. mutans and S. sobrinus in dental plaque, it may also be useful as a quantitative PCR to estimate the approximate numbers of these two species. In the quantitative PCR, DNA was prepared from known numbers of $S$. mutans (or $S$. sobrinus) cells, and the approximate numbers of the two species in dental plaque were determined by comparing the intensities of the species-specific amplicons from dental plaque sample with those from the standard DNA (data not shown). The ratio of two species in dental plaque shown by the quantitative PCR could be helpful to understand the relationship between caries incidence and cariogenic species prevalent in dental plaque.

It is of interest to understand the prevalence of $S$. sobrinus and $S$. mutans in the oral cavity. The PCR 
results shown in Table 2 revealed higher prevalence $(83 \%)$ of $S$. sobrinus than currently supposed $(0-50 \%)$ [3-5]. It is speculated that the difference depends on the detection method used: the detection method with PCR was performed directly on dental plaque without the culture step and biochemical tests; the conventional method needs several steps such as selective culture on an MSB plate followed by several confirmation tests. It has been reported that MSB inhibits the growth of $S$. sobrinus to a greater extent than $S$. mutans $[7,11]$. If this is true, $S$. sobrinus may consist of strains with different susceptibility to bacitracin. Further studies are needed to clarify this question, and the PCR-based detection method described here would be helpful for subsequent research.

\section{References}

1. Whiley RA, Beighton D. Current classification of the oral streptococci. Oral Microbiol Immunol 1998; 13: 195-216.

2. Hamada S, Slade HD. Biology, immunology, and cariogenicity of Streptococcus mutans. Microbiol Rev 1980; 44: 331-384

3. Loesche WJ. Role of Streptococcus mutans in human dental decay. Microbiol Rev 1986; 50: 353-380.

4. Carlsson P, Gandour IA, Olsson B, Rickardsson B, Abbas K. High prevalence of mutans streptococci in a population with extremely low prevalence of dental caries. Oral Microbiol Immunol 1987; 2: 121-124

5. Van Palenstein Helderman WH, Ijsseldijk M, Huis in't Veld JHJ. A selective medium for the two major subgroups of the bacterium Streptococcus mutans isolated from human dental plaque and saliva. Arch Oral Biol 1983; 28: 599-603.

6. Gold OG, Jordan HV, van Houte J. A selective medium for Streptococcus mutans. Arch Oral Biol 1973; 18: 1357-1364.

7. Jordan HV. Cultural methods for the identification and quantitation of Streptococcus mutans and lactobacilli in oral samples. Oral Microbiol Immunol 1986; 1: 23-30.

8. Svanberg M, Krasse B. Comparative recovery of mutans streptococci on two selective media. Caries Res 1990; 24: 36-38.

9. Wade WG, Aldred MJ, Walker DM. An improved medium for isolation of Streptococcus mutans. J Med Microbiol 1986; 22: 319-323.

10. Beighton D, Hardie JM, Whiley RA. A scheme for the identification of viridans streptococci. J Med Microbiol 1991; 35: $367-372$.

11. de Soet JJ, van Dalen PJ, Pavicic MJAMP, de Graaff J. Enumeration of mutans streptococci in clinical samples by using monoclonal antibodies. J Clin Microbiol 1990; 28:
2467-2472.

12. Russell RRB. Genetic analysis and genetic probes for oral bacteria. In: Ferguson DB (ed) Aspects of oral molecular biology. (Frontiers of oral physiology, vol 8). Basel, Karger 1991: $57-75$.

13. Smorawinska M, Kuramitsu HK. DNA probes for detection of cariogenic Streptococcus mutans. Oral Microbiol Immunol 1992; 7: 177-181.

14. Colby SM, Harrington DJ, Russell RRB. Identification and genetic characterization of melibiose-negative isolates of Streptococcus mutans. Caries Res 1995; 29: 407-412.

15. Ono T, Hirota K, Nemoto K, Fernandez EJ, Ota F, Fukui K. Detection of Streptococcus mutans by PCR amplification of spaP gene. J Med Microbiol 1994; 41: 231-235.

16. Colby SM, Whiting GC, Tao L, Russell RRB. Insertional inactivation of the Streptococcus mutans $\operatorname{dexA}$ (dextranase) gene results in altered adherence and dextran catabolism. Microbiology 1995; 141; 2929-2936.

17. Colby SM, Russell RRB. Sugar metabolism by mutans streptococci. Soc Appl Bacteriol Symp Series 1997; 26: $80 \mathrm{~S}-88 \mathrm{~S}$.

18. Barrett JF, Barrett TF, Curtiss R. Purification and partial characterization of the multicomponent dextranase complex of Streptococcus sobrinus and cloning of the dextranase gene. Infect Immun 1987; 55: 792-802.

19. Igarashi T, Yamamoto A, Goto N. Characterization of the dextranase gene $(\operatorname{dex} A)$ of Streptococcus mutans and its recombinant product in an Escherichia coli host. Microbiol Immunol 1995; 39: 387-391.

20. Igarashi T, Yamamoto A, Goto N. Sequence analysis of the Streptococcus mutans Ingbritt dexA gene encoding extracellular dextranase. Microbiol Immunol 1995; 39: 853-860.

21. Igarashi T, Yamamoto A, Goto N. Characterization of the dextranase purified from Streptococcus mutans Ingbritt. Microbiol Immunol 1992; 36: 969-976.

22. Wanda S-Y, Curtiss R. Purification and characterization of Streptococcus sobrinus dextranase produced in recombinant Escherichia coli and sequence analysis of the dextranase gene. $J$ Bacteriol 1994; 176: 3839-3850.

23. Ida $\mathrm{H}$, Igarashi $\mathrm{T}$, Goto $\mathrm{N}$, Sasa $\mathrm{R}$. Identification of Streptococcus mutans by $\operatorname{dexA}$ DNA probe. Pediatr Dent $J$ 1998; 8: $1-5$.

24. Igarashi T, Yamamoto A, Goto N. Direct detection of the Streptococcus mutans in human dental plaque by polymerase chain reaction. Oral Microbiol Immunol 1996; 11: 294-298.

25. Gillespie SH, Ullman C, Smith MD, Emery V. Detection of Streptococcus pneumoniae in sputum samples by PCR. J Clin Microbiol 1994; 32: 1308-1311.

26. Marmur J. A procedure of the isolation of deoxyribonucleic acid from micro-organisms. J Mol Biol 1961; 3: 208-218.

27. Tanzer JM, Clive J. Quantitative considerations in microbiological evaluations for caries: risks for type II errors resulting from use of MSB agar. Oral Microbiol Immunol 1986; 1: 28-30. 